\title{
Upacara Kalang Obong (Suatu Tinjauan Etno-Arkeologi)
}

\section{Hari Lelono}

Keywords: ethnography; ethnoarchaeology; tradition; kalang; ritual

\section{How to Cite:}

Lelono, H. (1989). Upacara Kalang Obong (Suatu Tinjauan Etno-Arkeologi). Berkala Arkeologi, 10(1), 1-9. https://doi.org/10.30883/jba.v10i1.533

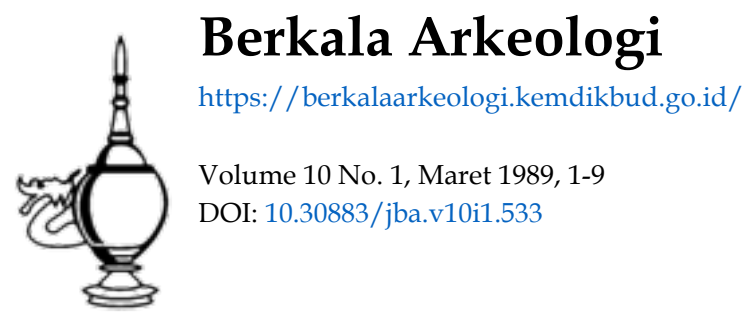




\section{UPACARA KALANG OBONG \\ ( Suatu Tinjauan Etno-Arkeologi )}

\section{Oleh: T.M. Hari Lelono}

I. PENDAHULUAN

Dalam masyarakat Jawa dikenal sekelompok periduduk yang disebut 'Wong Kalang' (Orang Kalang). Orang Kalang banyak yang menjadi pedagang kayu atau petani sukses, sehingga mereka hidup berkecukupan. Orang Kalang mendiami beberapa kota dan daerah tertentu, seperti Tegal Gendu (Kota Gede) Yogyakarta, Petanahan dan Ambal di Kebumen, Pekalongan, Semarang, Walikukun, Madiun, Tulungagung, Surabaya, dan di daerah Banyuwangi.

Orang Kalang dibedakan dua kelompok, yaitu Kalang Obong (Kalang Besmen), dan Kalang Kamplong, Kalang Obong mempunyai kebiasaan membakar boneka sebagai lambang orang yarig telah meninggal, pada hari keseribu (nyewu). Kalang Obong adalah keturunan dari Pancer Lanang (patrilineal), dan Kalang Kamplong dari keturunan Pancer Estri (matrilineal). Jadi Kalang Karnplong hanyalah pihak ibu yang berdarah Kalang, sedangkan suaminya dari masyarakat biasa (bukan Kalang). Golongan Kalang Kamplong tidak berhak mengadakan upacara obong (membakar puspa) (Pontjosutirta, 1988: 9).

Golongan Kalang sebenarnya sudah muncul dan disebut dalam prasasti Jawa Kuno. Prasasti Harinjing A (804 M) misalnya menyebut tuha kalang (ketua kelompok kalang) (Sukarto, 1985: 55). Selain itu, disebut pula dalam prasasti Panggumulan (904 M) dengan istilah Pande Kalang (tukang kayu) (Nastiti, 1982: 33). Pada abad IX-X, pengertian Kalang dikaitkan denqan tukang kayu (pengrajin kayu) ataul petugas kehutanan. Dalam kamus Old Javanese Dictionary (Zoetmulder, 1982: 772) 
perkataan Kalang diterjemahkan 'wood working building'? (pengrajin kayu, bangunan?). Di Keraton Surakarta dikenal abdi dalem kalang atau abdi dalem tukang kayu yang bekerja sama dengan abdi dalem narawreksa (nara: orang, wreksa: kayu). Di Keraton Yogyakarta beberapa waktu yang lalu dikenal abdi dalem gowong yang berkaitan pula dengan masalah perkayuan yang bertempat tinggal di daerah Gowongan Kodya Yogyakarta. Konon ceritanya, ${ }^{1}$ sewaktu Sultan Agung menggempur Batavia pada tahun 1628 (ekspedisi Kaladuta I) dan tahun 1629 (ekspedisi Kaladuta II) tugas orang Kalang adalah membawa keperluan para prajurit dengan menggunakan gerobak yang ditarik kerbau. Sejak jaman Sultan Agung (pertengahan abad XVII) penduduk yang mendiami hutan terasing di bagian tengah dan timur Pulau Jawa, yaitu: orang Pinggir, Gajah Mati, dan Kalang, dipindah ke kota atau perkampungan lain. Setelah dipindah, orang Kalang meneruskan pekerjaannya yang berkaitan dengan perkayuan. Sebagian lagi ada yang bertugas membawa perlengkapan para prajurit Mataram seperti disebutkan di atas.

Pada abad ke XVIII jumlah orang Kalang di Kerajaan Mataram cukup banyak. Pada atahun 1739 M, Susuhunan Paku Buwono II memberi hak kepada Tumenggung Surnadiningrat yang berkuasa di Kabupaten Sidayu untuk memerintah 6000 keluarga Kalang. Demikian pula sewaktu diadakan perjanjian pembagian kerajaan menjadi dua pada tahun 1755, Susuhunan Surakarta dan Sultan Yogyakarta masing-masing memerintah golongan Kalang sebanyak 3000 cacah (Pontjositirto, 1988: 7). Sejak tahun 1930 orang Kalang yang bertempat tinggal di Tegal Gendu, Kota Gede, diberi kepercayaan mengelola pegadaian oleh pemerintah Belanda. Sejak itu, nasib mereka bertambah baik dan banyak yang menjadi pedagang kaya. Tetapi sejak tahun 1945 banyak rumah mewah golongan orang Kalang ditinggalkan, dan bekas rumah itu dianggap rumah terkutuk oleh sebagian masyarakat di sekitarnya. 2 


\section{ASAL USUL ORANG KALANG}

Sebagian orang Jawa percaya dan mengatakan, bahwa orang Kalang mempunyai ekor. Kepercayaan itu berkaitan dengan cerita tentang asal usul orang Kalang yang dikaitkan dengan binatang tertentu, seperti anjing dan babi. Ada berbagai versi ceritera mengenai asal orang Kalang. Salah satu cerita mengatakan, bahwa pada jaman dahulu ada seorang pangeran yang pergi berburu ke dalam hutan diantar oleh para hambanya. Pada suatu saat pangeran itu kencing yang ditampung di dalam tempurung. Kemudian ada seekor babi betina yang haus dan meminum air kencing dalam tempurung tersebut sehingga akhirnya babi itu mengandung, dan beberapa búlan kemudian melahirkan seorang bayi perempuan. Bayi ditinggal di dalam hutan, dan ditemukan oleh seorang janda yang ditinggal di pinggir hutan dan kemudian merawatnya. Setelah dewasa, gadis itu menjadi perawan yang berparas ayu dan gemar menenun. Suatu saat ketika sedang menenun di atas rumah panggung yang tinggi, sebuah alat tenunnya jatuh. Gadis itu bernazar, siapa saja yang mengambilkannya, kalau lakilaki akan dijadikan suaminya, dan apabila perempuan akan dijadikan sahabat karibnya. Tiba-tiba datanglàh seekor anjing jantan menaiki tangga dan menyerahkan alat tersebut. Anjing tersebut menjadi suaminya, karena tidak dapat mengingkari janjinya. Dari perkawinan itu lahir seorang anak laki-laki yang tampan bernama Jaka Sona (sona: anjing). Pemuda itu gemar berburu ke dalam hutan, yang selalu ditemani seekor anjing yang setia (ayahnya). Ketika sedang berburu di hutan, Jaka Sona melihat seekor babi betina, dan menyuruh anjing peliharaannya mengejarnya. Tetapi anjing tersebut tidak mau menjalankan perintah Jaka Sona. Jaka Sona sangat marah, setelah membunuh babi betina itu, anjing yang selalu setia mengikutinya juga dibunuhnya. Setelah pulang ke rumah, Jaka Sona menguraikan kejadian tersebut kepada ibunya. Alangkah terkejutnya ketika ibunya menceritakan, bahwa babi betina itu sebetulnya 
neneknya sendiri dan anjing yang setia mengikutinya adalah ayahnya. Sangat sedih, akhirnya Jaka Sona meninggalkan ibunya dan mengembara ke dalam hutan. Keturunan Jaka Sona itulah yang akhirnya menjadi orang Kalang.

Versi lain mengaitkan asal-usul orang Kalang dengan Candi) Prambanan. Diceritakan setelah Bandung Bandawasa berhasil membangun Candi Sewu dalam waktu semalam tetapi ditolak lamarannya oleh Dewi Lara Jonggrang, karena kurang satu kemudian ia menghadap ayahnya Darmawangsa di Pengging. Bandung dimarahi dan dikutuk menjadi seekor anjing. Bandung Bandawasa yang telah berubah menjadi seekor anjing, mencari Dewi Lara Jonggrang yang menolak lamarannya, karena. Bandung Bondowoso telah membunuh Prabu Gopala, ayah Lara Jonggrang. Dewi Lara Jonggrang menyamar sebagai Temon atau Lara Kasihan dan bertempat tinggal di desa Kalangan. Pada suatu saat ketika Rara Temon sedang menenun, alat tenunnya jatuh, dan Rara Temon mengucapkan sumpah, siapa yang dapat mengambil dan menyerahkan akan dijadikan suaminya. Seekor anjing jelmaan Bandung Bandawasa mengambil dan menyerahkan alat tenun kepada Rara Temon yang akhirnya menjadi suaminya. Perkawinan antara Rara Temon dan anjing itu melahirkan seorang anak bernama Jaka Kalang. Setelah besar Jaka Kalang mengabdi ke tempat kakeknya di Pengging, dan menerima gelar Tumenggung Kalangdaya yang bertugas sebagai pegawai kehutanan atau undagi kayu.

Cerita lain mengatakan, bahwa Jaka Sona sebetulnya berasal dari Bali. Ia diusir meninggalkan Bali dan pindah ke Jawa, karena bersalah menghamili R. Ayu Ambarwuyung. Keduanya kemudian pindah ke Petanahan (daerah Kebumen). Jaka Sona beragama Hindu, dan $R$. Ayu Ambarwuyung beragama Islam. Keturunan Jaka Sona banyak yang menjadi petani dan menyebar di daerah Ambal (Kebumen), Ngotho dan Tegal Gendu (Yogyakarta), Sragen, dan Banyuwangi. 


\section{UPACARA OBONG}

Golongan Kalang Obong sampai sekarang masih mengenal upacara obong, yaitu membakar boneka puspa pada waktu nyewu (seribu hari setelah kematian seseorang). Upacara obong pernah berlangsung di desa Ngotho, Kelurahan Bangunjiwo, Kecamatan Sewon, Kabupaten Bantul, Yogyakarta, untuk memperingati seribu hari meninggalnya Ibu Rubinah Karyaprawira, bersamasama delapan orang lainnya. Upacara itu diselenggarakan pada tanggal 8 Agustus 1978, malam hari. Sebelum upacara dimulai seorang. sesepuh desa menguraikan riaksud upacara tersebut. Sementara itu, semua keturunan Ibu Rubinah Karyaprawira berdiri berjajar di beranda depan menghadap ke selatan. Keturunan putri berada di sebelah kiri, dan keturunan putra berada di sebelah kanan. Di tengah emper (bagian depan beranda) diletakkan seekor kerbau yang sudah diambil dagingnya, tetapi kepala kerbau dengan tanduknya yang panjang masih tetap utuh. Daging dimanfaatkan untuk menjamu perá undangan. Kerbau tersebut didudukkan dengan sikap duduk njerum dan di sekitarnya terdapat bermacam-macam sesajian (sajen). Sehelai kain putih ditetakkan di atas punggung kerbau disertai untaian bungabungaan.

Upacara dimulai sekitar pukul 21.00 WIB, setelah itu dilakukan upacara kirabing puspa (kirab : berjalan keliling). Puspa yang melambangkan orang yang telah meninggal diarak berkeliling sebanyak tiga kali dengan cara mengitari kerbau. Istilah puspa sebetulnya berarti 'bunga' yang dibuat dari sebilah papan kayu jati yang tidak bermata (tanpa soca), setinggi kira-kira $35 \mathrm{~cm}$. Puspa tersebut digores menggambarkan wajah orang dan dilengkapi dengan untaian bunga. Pembuatan puspa harus dilakukan oleh seorang dukun keturunan Kalang, yang saat upacara itu dibuat oleh Nyai Cakradiarja seorang penduduk Turi, Kelurahan Ngebruk, Kecamatan Barongan, Kabupaten Bantul, Yogyakarta. Jumlah puspa sebanyak sembilan buah, dibopong oleh sembilan orang 
cucu laki-laki (putu kakung) dari si mendiang, sedangkan cucu perempuan (putu estri) membawa saji-sajian. Kirabing puspa tersebut berjalan berkeliling mengirikan kerbau, sama halnya dengan arah Prasawyam (sawyam: kiri) yang sudah dikenal sejak masa Klasik (Hindu). Orang yang berjalan terdepan menuntun itik dan memegang pecut, diikuti oleh beberapa orang membawa alatalat pertukangan dan pertanian, seperti pahat (tatah) dan mata bajak (Kejhen). Selama berkeliling tatah dan kejhen tersebut dipukul sehingga menimbulkan suara ryaring. Setelah itu diikuti pembawa ponpon (kunyit, jahe, temulawak, temu ireng, dan lain-lainnya), kemudian diikuti pula oleh sembilan orang yang membopong puspa. Setelah mengelilingi kerbau sebanyak tiga kali dengan arah prasawyam, puspa diasapi dengan dupa kemenyan (dikutuki), dan diletakkan sebentar di punggung kerbau, lalu diangkat kembali. Setelah upacara di emper selesai, puspa kemudian diarak ke sebuah rumahrumahan yang disebut pancaka, yang beratap alangalarig dan terletak di sebelah timur rumah sejauh kurang lebih 100 meter di pinggir Kali Gajahwong. Arakarakan yang diikuti semua keluarga dan para tamu, berlangsung hingga sekitar pukul 24.00 WIB. Puspa diletakkan di pancaka, kemudian dibakar. Setelah api padam, sekitar satu jam atau dua jam kemudian, abu puspa dikumpulkan dan dilarung ke Kali Gajahwong. Hal ini dimaksudkan, bahwa abu puspa sudah bersatu dengan unsur panca-mahabhuta (air, api, angin, angkasa, dan tanah). Setelah penaburan abu puspa ke dalam sungai, maka selesailah upacara pembakaran obong tersebut.

\section{ULASAN SINGKAT}

Uraian di atas sudah cukup menggambarkan bahwa upacara obong merupakan salah satu sisa-sisa upacara agama Hindu yang pernah berkembang di Jawa. Sampai sekarang pun upacara pembakaran mayat (ngaben) masih tetap berlangsung di Bali, demikian pula pembakar- 
an boneka sebagai lambang orang yang telah meninggal.

Di Bali, upacara pembakaran mayat atau boneka lambarig orang yang telah meringgal, disebut ngaben untuk golongan Sudra dan pelebon (untuk bangsawan atau raja). Setelah ngaben masih dikenal pembakaran boneka dari uang kepeng atau kayu cendana yang disebut upacara nyekah (dari sekar: bunga). Orang Bali juga mengenal istilah puspasarira untuk menyebut boneka tersebut. Masyarakat Tengger mengenal upacara slametan entas-entas pada hari keseribu meninggalnya seseorang. Pada hari slametan entas-entas, nyawa dan tubuh orang yang meninggal dinaikkan (di-enthas-kan) ke sorga . dan berkumpul dengan para dewa. Orang Tengger menyebut boneka lambang orang yang telah meringgal itu dengan istilah petro (pitara: arwah nenek moyang) (Sukarto, 1960 : 404).

Ada hal menarik mengenai arah yang dilakukan sewaktu mengelilingi kerbau, yakni dilakukannya arah prasawyam yang sudah berkembang sejak masa Klasik (Hindu). Pada jaman pengaruh kebudayaan Hindu, arah yarig penting mengelilingi candi adalah pradaksina (daksina: kanan) searah dengan jarum jam (clock wise). Arah prasawyam maupun pradaksina keduanya merupakan arah suci, yang pada umumnya arah pradaksina dianggap lebih suci dan mulia. Sewaktu diadakan peringatan 238 tahun berdirinya Keraton Yogyakarta tanggal 8 Februari 1986, juga diselenggarakan tirakatan mubeng beteng (mengelilingi benteng keraton) secara membisu (tapa mbisu). Tirakatan mubeng beteng itu dipimpin oleh putra Hamengku Buwono IX, yaitu GBPH Joyokusumo dan BRM Sulasmono, yang diselenggarakan pada waktu malam hari. Ternyata tirakatan itu juga berjalan dengan arah mengirikan keraton (prasawyam), dengan menempuh jarak kurang lebih delapan kilometer.

Binatang kerbau pada masa megalithik sudah dipergunakan sebagai binatang yang mempunyai arti pen- 
ting. Tanduk kerbau sampai sekarang masih digunakan untuk menghiasi bagian depan rumah khususnya bagi orang Batak dan Toraja. Demikian pula dalam prasasti kuno kerapkali disebut tandas ning kbo (prasasti Wukajana) atau tandas ning hadangan (Kawi Oorkonden No. X). Kbo adalah sinonim hadangan. Penanaman kepala kerbau sampais ekarang masih dilakukan terutama pada waktu pembuatan jembatan, mendirikan gedıng yang megah, dan pada peristiwa penting lainnya. Maksudnya adalah agar segala sesuatunya berjalan lancar dan selamat, karena semua kendala atau hadangan akan ditolak (ditanduk) kerbau tersebut.

Pada waktu sekarang, nama Kalang juga dikaitkan dengan makam kuno prasejarah yang terdapat di Cepu atau Bojonegoro, yaitu kubur Kalang (pendheman wong kalang). Di daerah Wonosari disebut Kubur Budo (pendheman wong budo). Apakah peti mayat tersebut betulbetul makam orang Kalang, masih perlu diteliti lebih lanjut. Jalam beberapa prasasti, keberadaan orang Kalang (petugas hutan) sudah ada sejak abad ke IX Masehi (prasasti Harinjing). Perkataan Kalang dan Budo yang diterapkan untuk makam prasejarah itu juga berarti 'kuno', artinya kuburan yang tidak lagi diketahui maksudnya oleh masyarakat sekarang. Kubur Kalang pada umumnya membujur ke arah timur-barat atau arah gunung-lautan, berlainan dengan makam Islam yang membujur ke arah utara-selatan.

Demikian uraian singkat mengenai orang Kalang, yang sudah dikenal sejak jaman kuno sampai sekarang. Perielitian orang Kalang tersebut masih perlu dilanjutkan, mengingat bahwa mereka (khususnya orang Kalang di daerah Yogyakarta) masih mewarisi tradisi dari nenek moyangnya. Pada jaman dahulu mereka adalah petugas kehutanan atau yang berkaitan dengan pertukangan (tukang kayu) dan perundagian (undagi kayu). Pada saat ini kelompok orang Kalang sudah membaur dengan masyarakat lainnya, dan banyak di antaranya menjadi petani dan pedagang yang sukses. 


\section{Cataten :}

1. Informasi dari penduduk Tegal Gendu Kotagede Yogyakarta (Panitia Upacara Kalang Obong bulan Agustus 1987). Lihat pula kisah di Balik Persiapan Kaladuta III.

2. Hasil wawancara dengan penduduk sekitarnya, ada anggapan bahwa orang Kalang merupakan antek (kaki tangan) Belanda. Selain itu, mereka terkenal kikir terhadap penduduk di sekitarnya.

\section{DAFTAR ACUAN}

Nastiti, Titi Surti, dkk. 1982 "Tiga Prasasti Dari Masa Balitung", Pusat Penelitian Arkeologi Nasional, PT. Bunda Karya, Jakarta.

Pontjosutirto, Soelarjo. 1988. "Beberapa Hal Mengenai Orang Kalang", Makalah pada Ceramah rutin di Museum Sonobudoyo, Yogyakarta.

Atmodjo, Sukarto K., 1960. "Topeng Sang Hyang Puspasarira", (?), Sana Budaya, Tahun ke-1, No. 9, Desember 1960, Jawatan $\mathrm{P}$ dan K Daerah Istimewa Yogyakarta, Yogyakarta.

Atmodjo, Sukarto K., 1985. "Sekitar Masalah Sejarah Kediri Kuna", makalah pada Seminar Sejarah Kediri Kuna, Lembaga Javanologi \& Universitas Kediri, Yogyakarta.

Zoetmulder, S.J, P.J., 1982. Old Javanese - English Dictionary, KITLV (Koninklijk Instituut Voor Taal Land-en Volkenkunde). 